\title{
СВОТ-АНАЛІЗ ЯК ІНСТРУМЕНТ УПРАВЛІННЯ МІЖНАРОДНОЮ КООПЕРАЦІЕЮ ЗАКЛАДІВ ВИЩОЇ ОСВІТИ
}

\author{
Светлана Бебко
}

\section{СВОТ-АНАЛИЗ КАК ИНСТРУМЕНТ УПРАВЛЕНИЯ МЕЖДУНАРОДНОЙ КООПЕРАЦИЕЙ ВЫСШИХ УЧЕБНЫХ ЗАВЕДЕНИЙ}

\author{
Svetlana Bebko

\section{SWOT-ANALYSIS AS A TOOL FOR MANAGING THE INTERNATIONAL COOPERATION OF HIGHER EDUCATION INSTITUTIONS}

У статті розглянуто основні поняття, пов'язані з кооперацією, а також особливості міжнародної кооперації закладів вищої освіти. За допомогою інструментарію стратегічного управління, зокрема СВОТ-аналізу, виявлено основні переваги та проблеми міжнародної кооперації закладів вищої освіти Украӥни, визначено можливості й загрози, шуо створює для неї зовнішнє середовище, вплив об'єктивних факторів, якого важко або неможливо уникнути, проте необхідно реагувати. Доведено, ще використання СВОТ-аналізу як інструменту управління міжнародною кооперацією університетської освіти дає можливість не лише оцінити ї̈ сильні $і$ слабкі сторони, можливості й загрози, але скористатися одержаною інформачією для побудови стратегії ї̈ подальшого розвитку в умовах мінливого глобалізованого світу, жорсткої конкуренції з боку потужної системи вищзӧ освіти розвинених краӥн Свропи та світу $i$, як результат, забезпечити ефективну реалізацію місї̈ вітчизняної вищої школи.

Ключові слова: заклади вищзӧ освіти; міжнародна кооперація; співробітництво; інтернаціоналізація; СВОТаналіз; можливості; загрози; переваги; аналіз; управління.

Рис.: 1. Бібл.: 12

В статье рассмотрены основные понятия, связанные с кооперацией, а также особенности международной кооперации высших учебных заведений. С помощью инструментария стратегического управления, в частности СВОТ-анализа, выявлены основные преимущества и проблемы международной кооперации высших учебных заведений Украины, определены возможности и угрозы, создаваемые для нее внешней средой, влияние объективных факторов, которого трудно или невозможно избежать, однако необходимо на него реагировать. Доказано, что использование СВОТ-анализа как инструмента управления международной кооперацией университетского образования дает возможность не только оиенить ее сильные и слабые стороны, возможности и угрозы, но и воспользоваться полученной информацией для построения стратегии его дальнейшего развития в условиях меняюшегося глобального мира, жесткой конкуренции со стороны мощной системы высшего образования развитых стран Европь и мира и, как результат, обеспечить эффективную реализацию миссии отечественной высшей школьл.

Ключевые слова: высшие учебные заведения; международная кооперация; сотрудничество; интернационализация; СВОТ-анализ; возможности; угрозы; преимущества; анализ; управление.

Pис.: 1. Библ.: 12.

The article considers the basic concepts related to cooperation, as well as the features of international cooperation of higher education institutions. With the help of strategic management tools, in particular SWOT-analysis, the main advantages and problems of international cooperation of higher education institutions of Ukraine are identified, opportunities and threats posed by the external environment, the influence of objective factors, which is difficult or impossible to avoid, but need to respond. It is proved that the use of SWOT analysis as a tool for managing international cooperation of university education makes it possible not only to assess its strengths and weaknesses, opportunities and threats, but also to use the information received to build a strategy for its further development in a changing global world, tough competition from a powerful system of higher education in developed countries of Europe and the world, and, as a result, to ensure the effective implementation of the mission of the domestic higher school.

Keywords: higher education institutions; international cooperation; cooperation; internationalization; SWOT analysis; capabilities; threats; advantages; analysis; control.

Fig.: 1. References: 12.

JEL Classification: I23; F69; D78

Постановка проблеми. За останню чверть століття українська вища освіта зазнала суттєвих змін, перетворившись із такого собі «камерного моноліту», уламка єдиної, цілісної системи вищої освіти величезної країни з плановою економікою і жорстким державним регулюванням, на досить строкату сукупність надавачів освітніх послуг, що мають багато відмінностей - від незначних до принципових - у своєму баченні стратегічних перспектив розвитку системи вищої освіти країни загалом. Водночас такі зміни відкрили безліч можливостей для всіх учасників освітнього процесу, розгорнули паліт- 
ТЕОРЕТИЧНІ ПРОБЛЕМИ РОЗВИТКУ НАЦІОНАЛЬНОЇ ЕКОНОМІКИ

ру альтернатив подальшого розвитку, поставили заклади вищої освіти (ЗВО) перед вибором, що вимагає не лише певних дій, але й відповідальності за їхні наслідки та, що найголовніше, усвідомлення цієї відповідальності.

Процес розвитку будь-якої системи, у тому числі й системи вищої освіти України, повинен базуватися на відповідних принципах, науково обгрунтованих, обдуманих рішеннях і забезпечувати досягнення головної мети, що визначається місією і призначенням цієї системи - формування інтелектуального і професійного потенціалу країни, нагромадження людського капіталу як основного інтенсивного продуктивного чинника економічного розвитку держави. Цей процес має бути керованим, а отже, вимагає усвідомленого підходу до управління, фахової побудови стратегії, вибору стратегічних альтернатив на основі використання відповідного інструментарію.

Сьогодні у сфері вищої освіти чи не найбільш визначальним є процес їі інтернаціоналізації, за якого надання освітніх послуг набуває міжнародного характеру, а на рівні окремого закладу вищої освіти - міжнародний аспект «вживлюється» в усі компоненти управління. Практична реалізація цього процесу відбувається у формі міжнародної кооперації закладів вищої освіти. Успіх кожного з них, досягнення поставлених цілей, отримання вигід від кооперації залежить від ефективності управління, яка, у свою чергу, визначається повнотою інформації, іiі якістю, достовірністю, вмінням коректно іiї зібрати та грамотно нею скористатися.

Аналіз останніх досліджень і публікацій. У будь-якому суспільстві, у будь-якій діяльності людей завжди має місце співпраця або кооперація. Саме тому питанням дослідження іiі сутності та особливостей у різних сферах присвячена величезна кількість праць, думок, висновків, зокрема таких знаних економістів, діячів-кооператорів і засновників кооперативного руху, як К. Пажитнов, В. Тотоміанц, М. Гібнер, О. Гдєшинський, С. Прокопович, М. Туган-Барановський, О. Чаянов, Б. Мартос, Р. Оуен, В. Райффайзен, Ш. Фур'є, Л. Луцатті, М. Левитський, а також таких сучасних вітчизняних і закордонних науковців, як В. Гончаренко, В. Зіновчук, Г. Скляр, С. Бабенко, М. Окландер, $\Phi$. Горбонос, А. Пантелеймоненко та багато інших.

Сучасні дослідження питань міжнародної кооперації закладів вищої освіти здійснюються переважно через призму інтеграційних процесів, міжнародного співробітництва, інтернаціоналізації університетської освіти, зовнішньоекономічної діяльності ЗВО. Ці та інші питання розвитку вищої школи, іiї інтеграції у світовий освітній простір, підвищення якості освіти, нарощування людського потенціалу висвітлено в наукових працях Ф. Андрушкевича, В. Андрущенка, Т. Антонюк, В. Бакирова, Л. Білого, Т. Боголіб, А. Бойко, Я. Болюбаша, О. Верхогляд, Ю. Грищук, Ж. Дерій, М. Згуровського, І. Каленюк, І. Козинець, О. Кондур, К. Корсака, В. Кременя, О. Кукліна, К. Левківського, В. Лугового, С. Ніколаєнка, В. Огнев’юка, С. Пакуліна, М. Степка, Т. Фінікова, Н. Холявко, Л. Чайки-Петегирич та інших.

Досягнення мети та одержання позитивних ефектів від міжнародної кооперації закладів вищої освіти можливе лише за умов професійного управління, побудованого на стратегічному підході з використанням усього спектра сучасного інструментарію, що дозволяє приймати обгрунтовані рішення. Питання розробки стратегії, стратегічного бачення системи, оцінки іiі сильних і слабких сторін, можливостей і загроз для іiї розвитку знайшли своє відображення в дослідженнях таких науковців, як С. Большенко,
Д. Горєлов, Л. Довгань,
С. Жукевич,
В. Микитенко,
О. Мініна,
В. Нємцов, 3. Шершньова та інші. Деякі аспекти стратегічного управління в системі вищої освіти України розглядаються в дослідженнях В. Вознюка, Н. Галяндіна, М. Гладченка, В. Гуменюка， П. Дудка， Т. Жорняк， С. Натрошвілі, I. Нємцевої, I. Семенець-Орлової, О. Скібіцького, С. Смерічевської, Л. Щоголєвої та деяких інших. 
Виділення недосліджених частин загальної проблеми. Велика кількість проведених на сьогодні наукових досліджень щодо розвитку вищої школи України свідчить про iii не найкращий стан, зумовлений багатьма проблемами системного характеру, впливом об'єктивних і суб'єктивних чинників, що визначають траєкторію іiї руху, внутрішніми суперечностями й іншими причинами. Опікуючись питаннями виживання, підтримання статусу, загострення конкуренції на ринку освітніх послуг, вітчизняна вища освіта ризикує не лише втратити свою ідентичність, але навіть і суб'єктність у світовому освітньому просторі. Тут не йдеться про зникнення української вищої школи як такої, а про втрату нею автономії, пригнічення іiі розвитку агресивним впливом зовнішнього світу. 3 огляду на це можна вважати недостатніми зусилля щодо формування стратегічного бачення майбутнього вітчизняної вищої освіти в сучасному глобалізованому світі, iіi інтернаціоналізації шляхом поглиблення міжнародної кооперації ЗВО і пошуків ефективних механізмів управління цим процесом.

Мета статті. Головною метою статті $\epsilon$ виявлення за допомогою інструментарію стратегічного аналізу сильних і слабких сторін вітчизняної вищої школи та міжнародної кооперації закладів вищої освіти, аналіз можливостей і загроз цьому процесу з боку зовнішнього середовища з метою визначення прийнятних альтернатив розвитку університетської освіти, іiі інтернаціоналізації та ефективної інтеграції у світовий освітній простір.

Виклад основного матеріалу. Розвиток сучасної вищої освіти будь-якої країни в умовах глобалізованого світу неможливо уявити поза процесом іiі інтернаціоналізації, що відбувається у формі міжнародної кооперації.

Протягом усієї історії еволюції суспільства, незалежно від рівня його соціальноекономічного розвитку, суспільного ладу, політичного устрою, ми можемо спостерігати ті чи інші форми взаємодії та співпраці людей, застосування яких дозволяє знижувати витрати на досягнення мети, вирішувати складні завдання i, врешті-решт, перетворювати деякі з них із недосяжних на цілком реальні. Усі ці види взаємодії отримали назву «кооперація» (від латинського cooperation - співробітництво, співпраця, тобто спільна робота або спільна праця). Свого часу В. Тотоміанц назвав кооперацію спільною дружною роботою: «там, де двоє дружними зусиллями підняли важкий для кожного 3 них окремо камінь, відбулася кооперація» [8]. У сучасному розумінні термін з'явився ще в XIX ст., і його появою ми завдячуємо одному 3 перших соціальних реформаторів XIX ст. англійському філософу, педагогу й соціалісту Р. Оуену. Незважаючи на провали його практичних експериментів, Р. Оуена вважають батьком кооперації, завдяки йому теоретичні дослідження цього явища почали набувати поширення i, зрештою, оформилися в кооперативний рух, що охопив усі види людської діяльності. Як зазначав О. Чаянов, «сторін життя, куди може проникнути кооперація, нескінченна множина» [12].

Незаперечні переваги кооперації дозволили їй пройти шлях від найпростіших форм співпраці декількох осіб до найскладніших видів співробітництва, що є затребуваним у всіх сферах суспільного життя. Не $є$ винятком і галузь вищої освіти. Виникаючи на першому етапі як розрізнені, відірвані один від одного, точкові акти взаємодії між окремими вітчизняними і закордонними закладами вищої освіти, міжнародна кооперація набувала ознак системності та інтернаціоналізації, що розвивається не стихійно, а планомірно й керовано. Досягнення найкращого результату співробітництва можливе в цьому випадку лише завдяки ефективним управлінським впливам, заснованим насамперед на принципі цілеполягання. Це один із ключових принципів глобального співробітництва в системі Україна - СС [5].

Основна мета міжнародної кооперації закладів вищої освіти - отримання синергійного ефекту від співробітництва, зокрема: 
ТЕОРЕТИЧНІ ПРОБЛЕМИ РОЗВИТКУ НАЦІОНАЛЬНОЇ ЕКОНОМІКИ

- виконання спільними зусиллями представників закладів вищої освіти різних країн робіт, проєктів, досліджень і досягнення результатів, які були б неможливими за умов відсутності кооперації;

- суттєве підвищення інтенсивності та результативності праці кожної зі сторін співробітництва;

- економія витрат, передусім трудових, за рахунок можливості широкого використання переваг спеціалізації, що не обмежується рамками одного ЗВО і навіть однієї країни;

- поява можливостей (за рахунок об’єднання фінансових, матеріальних, технічних, організаційних ресурсів) виконання тих видів робіт, реалізація яких або недоступна зусиллями одного закладу (однієї країни), або вимагає часу більше, ніж це виявляється економічно доцільним з погляду очікуваного результату;

- поява можливостей виконання робіт, обмежених у часі;

- поява можливостей дослідження процесів, явищ, змін, що мають глобальну географію і відбуваються одночасно;

- формування нових компетенцій, отримання нового, часто унікального, досвіду та навичок учасниками коопераційної взаємодії;

- підвищення якості освітніх послуг за рахунок нових компетенцій тощо.

Досягнення цілей міжнародної кооперації сприяє, у свою чергу, реалізації місії вищої освіти країни загалом, що у проєкті «Стратегії розвитку вищої освіти в Україні на 2021-2031 роки» визначена так: «Місія вищої освіти - забезпечення сталого інноваційного розвитку України через підготовку висококваліфікованих фахівців, створення та поширення знань, формування інтелектуального, соціального та духовного капіталу суспільства, готового до викликів майбутнього» [10].

Чи зможе і якщо так, то наскільки ефективно, сприяти реалізації визначеної місії міжнародна кооперація закладів вищої освіти, залежить від ефективності управління цим процесом, що має базуватися на стратегічному підході. Як зазначає О. Мініна, стратегічний підхід полягає в перетворенні будь-яких змін на позитивні можливості та їх використання. Ознака відсутності стратегічного підходу - концентрація організації на внутрішніх ресурсах. Тим самим ігноруються всі можливі загрози ззовні (вони сприймаються тільки як факт, що здійснився) і упускаються сприятливі тенденції [6].

Формування стратегічного погляду на перспективи розвитку міжнародної кооперації, вибір стратегічних альтернатив можливий лише за наявності об'єктивно сформованого інформаційного кейса, врахування всіх переваг, недоліків, можливостей і загроз, що є в цій сфері, якості прогнозу тенденцій та об'єктивності оцінки ризиків.

Одним із найбільш зручних, простих і водночас якісних інструментів стратегічного аналізу є технологія CBOT (з англ. SWOT Analysis). Це метод оцінювання внутрішніх та зовнішніх факторів, які впливають на розвиток об'єкта дослідження (організації, проєкту, процесу), у нашому випадку - міжнародної кооперації закладів вищої освіти. Він допомагає оцінити сильні та слабкі сторони цього процесу, знайти нові можливості та визначити ймовірні загрози. Ефективність методу підтверджується тим, що починаючи з 1980-х років XX ст. СВОТ-аналіз активно застосовується для розробки стратегічних рішень і не втратив своєї актуальності за весь час існування в інструментарії менеджменту.

Можливості й загрози є факторами зовнішнього середовища - такими, що можуть вплинути на процес міжнародної кооперації 3ВО і при цьому не контролюються жодним 3 них. Це, переважно, чинники макросередовища, які характеризують політикоправове, економічне, соціокультурне, технологічне середовище міжнародного співробітництва. Сприятливі фактори цього середовища створюють можливості (Opportunities) для розвитку кооперації між 3ВО різних країн, спонукають активізувати цей процес і 
забезпечують умови для одержання вигід від нього. Їх слід аналізувати, оцінювати та максимально використовувати. Натомість загрози (Threats), або негативні фактори зовнішнього середовища, можуть суттєво уповільнити процес міжнародної кооперації, послабити позиції вітчизняної вищої школи на світовому ринку освітніх послуг. Оскільки загрози означають евентуальні ризики в майбутньому, кожна 3 них має бути ретельно проаналізована, оцінена 3 погляду ймовірності виникнення в найближчій, а також віддаленій перспективі, та максимально «знешкоджена» продуманими, обгрунтованими стратегічними рішеннями.

Сильні та слабкі сторони є чинниками внутрішнього середовища. Вони визначають внутрішній стан, потенцію і, значною мірою, ефективність процесу міжнародної кооперації у сфері вищої освіти, її переваги і недоліки, системний вплив на якість освіти, ефективність і конкурентоспроможність окремих ЗВО та національної системи вищої освіти загалом. Сильні сторони (Strengths) міжнародної кооперації забезпечують закладу вищої освіти формування конкурентних переваг на ринку освітніх послуг або більш вигідне становище порівняно з конкурентами. Водночас на процес співробітництва впливають також і сильні сторони, або переваги самого ЗВО, його стратегічний потенціал, сукупність компетенцій, навичок, завдяки яким він відчуває себе краще і стабільніше конкурентів. Для досягнення цілей кооперації сильні сторони необхідно максимально використовувати. Слабкі сторони або недоліки, обмеження (Weaknesses) - це такі внутрішні характеристики ЗВО і самого процесу співробітництва, які ускладнюють розвиток міжнародної кооперації, заважають посісти провідні позиції на ринку освітніх послуг, підвищувати їхню якість, створюють загрозу конкурентоспроможності академічної освіти. Необхідно відстежувати напрями, за якими ЗВО не досить сильний або кооперація має обмеження, підсилювати їх, розробляти спеціальні програми для мінімізації ризиків впливу слабких сторін на ефективність міжнародної кооперації.

Слід зазначити, що за допомогою СВОТ-аналізу можна дати структурований опис стану вищої освіти та перспектив іiї інтернаціоналізації, проте для одержання практичного результату має сенс сформувати стратегічні альтернативи подальших дій на перетині полів, які передбачають комбінування різних варіантів можливостей, загроз, сильних і слабких сторін та стратегії подальшого розвитку для найкращого їх врахування i використання. Зокрема, сильні сторони можна використовувати, щоб отримати віддачу від можливостей у зовнішньому середовищі, або для усунення загроз. 3 іншого боку, за рахунок можливостей зовнішнього середовища можна подолати наявні слабкості або найкраще використати сильні сторони. За найгіршої комбінації зовнішніх і внутрішніх чинників стратегічні рішення мають визначати першочерговий перелік слабкостей, яких необхідно позбутися, щоб запобігти загрозам зовнішнього середовища (рис. 1).

Узагальнюючи фактори зовнішнього середовища, можна зазначити, що на сьогодні найбільшим викликом для вищої освіти не лише України, але й усього світу стала пандемія - непрогнозована глобальна проблема, яка принципово змінила звичне життя людей, породила багато труднощів і незручностей, проте і стимулювала пошук шляхів забезпечення освітнього процесу в умовах обмеженості фізичного контакту, розкривши нові можливості й перспективи для розвитку вищої освіти у глобальному масштабі. Однак непрогнозовані наслідки пандемії для майбутнього, іiї негативний вплив на загальний економічний і фінансовий стан країн, зменшення комунікації та інші наслідки треба все ж таки розглядати як загрози для розвитку міжнародної кооперації закладів вищої освіти. 


\begin{tabular}{|c|c|c|}
\hline \begin{tabular}{r|} 
ВНУТРІШНІ \\
чИННИКИ \\
$\qquad$ \\
\end{tabular} & $\begin{array}{l}\text { Сильні сторони: } \\
\text { • потужний науковий потенціал } \\
\text { національної вищої школи; } \\
\text { • високий рівень професійної ком- } \\
\text { петентності викладачів; } \\
\text { • високий рівень авторитету ряду } \\
\text { вітчизняних ЗВО за кордоном; } \\
\text { • сформовані традицї̈ міжнарод- } \\
\text { ного співробітництва ЗВО; } \\
\text { • висока мотивація українських } \\
\text { здобувачів вищої освіти, науковців } \\
\text { і викладачів щодо розвитку між- } \\
\text { народного співробітництва; } \\
\text { • наявність досвіду дистанційного } \\
\text { навчання; } \\
\text { • успішний перехід до студенто- } \\
\text { орієнтованої вищої освіти } \\
\end{array}$ & $\begin{array}{l}\text { Слабкі сторони: } \\
\text { • недостатнє застосування передових освітніх } \\
\text { методик; } \\
\text { • фінансова нестабільність; } \\
\text { • відставання у рівні запровадження інновацій- } \\
\text { них технологій; } \\
\text { • низький рівень матеріально-технічного та ін- } \\
\text { фраструктурного забезпечення; } \\
\text { • недостатня комерціалізація наукового потен- } \\
\text { ціалу вищої освіти; } \\
\text { • низька зовнішня мобільність науково- } \\
\text { педагогічних працівників; } \\
\text { • низький рівень володіння іноземними мовами; } \\
\text { • ресурсна асиметричність міжнародної спів- } \\
\text { праці; } \\
\text { • низька активність вітчизняних ЗВО в організа- } \\
\text { ційних процесах міжнародного співробітництва }\end{array}$ \\
\hline Можливості: & СиМ-стратегії & \begin{tabular}{|c|} 
СлМ-стратегії \\
\end{tabular} \\
\hline $\begin{array}{l}\text { • запит з боку національної і світової економіки на інноваційні розробки; } \\
\text { • зростання попиту на висококваліфіковану робочу силу; } \\
\text { • запит глобалізованої системи світу на космополітичну світоглядну } \\
\text { орієнтацію суспільства; } \\
\text { • стрімкий розвиток інформаційних комунікативних технологій; } \\
\text { • перехід від елітарної до масової вищої освіти в усьому світі; } \\
\text { • зростаюча глобалізація, розширення міжнародних взаємодій; } \\
\text { • формування універсального суспільства знань }\end{array}$ & $\begin{array}{c}\text { Акумулювання наявного науково- } \\
\text { го потенціалу з метою нарощуван- } \\
\text { ня міжнародної кооперації, підви- } \\
\text { щення якості вищої освіти, } \\
\text { збільшення кількості кваліфікова- } \\
\text { них кадрів та інноваційних розро- } \\
\text { бок }\end{array}$ & $\begin{array}{c}\text { На фоні зростаючого запиту з боку глобального } \\
\text { світу активізація впровадження прогресивних } \\
\text { методик, інноваційних технологій, вивчення } \\
\text { мов, пошук форм міжнародного співробітницт- } \\
\text { ва, що дозволить комерціалізувати науковий } \\
\text { потенціал вищої школи, покращити матеріаль- } \\
\text { но-технічне забезпечення, зменшити відставан- } \\
\text { ня від іноземних університетів } \\
\end{array}$ \\
\hline \begin{tabular}{|c|} 
Загрози: \\
\end{tabular} & Си3-стратегіï & Сл3-стратегї \\
\hline $\begin{array}{l}\text { • потужне глобальне конкурентне середовище на ринку освітніх послуг; } \\
\text { • загострення геополітичної конкуренції провідних країн світу за інте- } \\
\text { лектуальні ресурси; } \\
\text { • загальноекономічні кризові явища в Україні та світі; } \\
\text { • політична нестабільність в Україні; } \\
\text { • криза вищої освіти у світовому масштабі; } \\
\text { • обмеження мобільності через пандемію; } \\
\text { • незавершеність трансформаційних процесів в Україні; } \\
\text { • відсутність ефективної системи фінансування вищої освіти } \\
\end{array}$ & $\begin{array}{c}\text { На основі використання потужно- } \\
\text { го наукового потенціалу закріпи- } \\
\text { тися у відповідних сегментах, ук- } \\
\text { ріпити імідж вітчизняної вищої } \\
\text { освіти, пропонуючи найкращі та } \\
\text { найефективніші практики і досвід } \\
\text { викладання, популяризуючи най- } \\
\text { прогресивніші результати україн- } \\
\text { ських наукових досліджень } \\
\end{array}$ & $\begin{array}{c}\text { Мінімізація неефективних взаємодій, протисто- } \\
\text { яння атакам з боку ключових конкурентів, на- } \\
\text { давання переваги якісним показниками міжна- } \\
\text { родної кооперації проти кількісних, } \\
\text { впровадження ефективної ресурсозберігаючої } \\
\text { стратегії. Мінімізація наслідків пандемії завдя- } \\
\text { ки розвитку й удосконаленню навичок дистан- } \\
\text { ційної взаємодії та освоєння комунікативних } \\
\text { технологій } \\
\end{array}$ \\
\hline
\end{tabular}


Вплив подібних загальносвітових проблем, які безпосередньо позначаються на соціально-економічному добробуті, відтерміновує вирішення питань міжнародної кооперації - кожна країна, кожен заклад вищої освіти намагається вирішити нагальні проблеми безпеки свого майбутнього, що $є$ на часі.

Як зовнішні загрози слід також зазначити кризу вищої освіти, що, на думку експертів, набула світових масштабів, проявляючись у зниженні якості освітніх послуг, рівня знань і компетенцій, одержуваних здобувачами, відставанні наукових напрацювань від запитів реальної економіки й суспільства, розриві між вищою освітою та умовами життя суспільства.

Інтернаціоналізації системи вищої освіти України загрозу також створює потужне конкурентне середовище на глобальному ринку освітніх послуг і наукових інноваційних розробок, сформоване провідними університетами - світовими лідерами цього ринку. Зростання мобільності здобувачів, викладачів, науковців, відкритості й доступності академічної освіти ще більше загострює конкурентну боротьбу, робить їі умови жорсткішими. Одночасно геополітична конкуренція провідних країн світу за інтелектуальні ресурси [11] підсилює загрози, оскільки на фоні несприятливих умов для розвитку наукового потенціалу в Україні, відсутності ефективної системи фінансування вищої освіти і науки спостерігається «відтік мізків», що загрожує послабленням позицій вітчизняних університетів та уповільненням процесів їх міжнародної кооперації.

Серед можливостей, що створює макросередовище, насамперед слід виділити загальносвітові тенденції, пов'язані з глобалізацією, інтеграцією та всіма супровідними процесами - розширенням міжнародних взаємодій, підвищенням мобільності людей, розвитком інформаційних технологій, що полегшують комунікацію, i, в кінцевому підсумку - формування запиту глобалізованої системи світу на космополітичну світоглядну орієнтацію суспільства. Це генерує нові можливості для вищої освіти і відкриває нові горизонти для іiї інтернаціоналізації через розвиток міжнародної кооперації ЗВО.

Окремо варто виділити можливості, створювані зовнішнім середовищем, безпосередньо дотичним до вищої освіти, що мають як освітній, науковий, так і прикладний характер та виступають безпосередніми рушіями ії розвитку. Це, зокрема, зростання запиту з боку національної і світової економіки на інноваційні розробки, постійне зростання попиту на висококваліфіковані кадри, інтернаціоналізація попиту і пропозиції освітніх послуг, перехід від елітарної до масової вищої освіти, що відбувається в усьому світі, формування універсального суспільства знань.

Нейтралізувати загрози і правильно скористатися можливостями в процесі розвитку міжнародної кооперації вітчизняні 3ВО можуть завдяки сильним сторонам вищої освіти та перевагам кооперації. За останні роки університетська освіта України суттєво змінилася i, попри певні втрати, має досить потужний науковий потенціал, високий рівень професійної компетентності викладачів, а певна кількість вітчизняних ЗВО користуються авторитетом за кордоном. Зокрема, багато університетів України присутні в міжнародному рейтингу ЗВО у 2018 р., що включив 1000 найкращих університетів світу. Це такі заклади, як, наприклад, Київський національний університет імені Тараса Шевченка (411-420), Харківський національний університет імені В. Н. Каразіна (401-410), Національний технічний університет України «Київський політехнічний інститут імені Ігоря Сікорського» (501-550), Національний технічний університет «Харківський політехнічний інститут» (700-750) [9]. Крім того, кількість здобувачів, що приїжджають до України на навчання, постійно зростає. Зокрема, якщо в 2016 р. в нашій державі навчалося 64 066, то на сьогодні вже 80470 іноземних студентів зі 158 країн світу [7]. 
ТЕОРЕТИЧНІ ПРОБЛЕМИ РОЗВИТКУ НАЦІОНАЛЬНОЇ ЕКОНОМІКИ

Перевагами і сильними сторонами вітчизняної вищої школи $є$ і сформовані за останні роки традиції міжнародного співробітництва ЗВО (спільна науково-педагогічна робота, академічний обмін та навчання, спільна видавнича робота тощо), висока вмотивованість українських здобувачів вищої освіти, науковців і викладачів щодо розвитку міжнародного співробітництва, підтримка ідеї міжнародної кооперації, наявність досвіду дистанційного навчання i, що найважливіше, успішний перехід до студентоорієнтованої вищої освіти.

Не слід, однак, залишати поза увагою слабкі сторони, або недоліки, що можуть негативно вплинути на інтернаціоналізацію вищої освіти. Серед «провалів» переважної більшості наших 3ВО нині залишається низький рівень матеріально-технічного та інфраструктурного забезпечення i, відповідно, ресурсна асиметричність міжнародної співпраці, недостатність передових методик і методологій освітніх послуг, зниження якості освіти, розрив у рівні запровадження інноваційних технологій, недостатня комерціалізація наукового потенціалу вищої освіти, низький рівень володіння іноземними мовами та цифрової грамотності, суттєва диференціація якісних показників науковопедагогічних працівників, їх низька зовнішня мобільність, низька активність вітчизняних 3ВО в організаційних процесах міжнародного співробітництва, його несистемний характер. В усуненні цих недоліків і слабких сторін не можна не зазначити важливу роль держави, без допомоги якої на нинішньому етапі це майже неможливо. Держава може взяти на себе завдання зміцнення матеріально-технічного потенціалу, процес створення умов та організаційного супроводження міжнародної кооперації, підтримку розвитку людського і наукового потенціалу, фінансування участі вітчизняних ЗВО в перспективних міжнародних проєктах тощо [1-4].

Практична користь СВОТ-аналізу як інструменту управління полягає в можливості систематизації отриманої інформації та розгляд на її основі ймовірних варіантів стратегічного розвитку міжнародної кооперації ЗВО. У СВОТ-матриці утворюються чотири квадранти, що характеризують комбінації можливостей, загроз, сильних і слабких сторін, даючи повну картину для прийняття обгрунтованих управлінських рішень (рис. 1).

Поле СиМ описує стратегії зростання. Грамотне використання сильних сторін вітчизняної вищої школи дозволить скористатися можливостями, що створює макросередовище, та суттєво наростити темпи інтернаціоналізації вищої освіти, поглибити міжнародну кооперацію ЗВО. Перелік можливих результатів охоплює: підвищення рівня професіоналізму професорсько-викладацького складу, престижності вітчизняних ЗВО, популяризацію української науки, уніфікацію програм підготовки фахівців, підвищення якості вищої освіти тощо.

Поля СлМ, СиЗ і СлЗ описують стратегії захисту, що дозволяють, скориставшись можливостями, створеними зовнішнім середовищем, подолати слабкі сторони, укріпити свій статус і покращити становище або, використовуючи сильні сторони, усунути загрози з боку зовнішнього середовища. У найгіршому випадку необхідно грунтовно підійти до розробки антикризової програми, що дозволить поступово усувати слабкі сторони й уникати або мінімізувати зовнішні ризики. Як результат, можна очікувати покращення використання людського потенціалу, створення сприятливого іміджу на міжнародному ринку освітніх послуг, формування стійких зв'язків з іноземними ЗВО, підвищення рівня кваліфікації, професіоналізму та практичного досвіду професорсько-викладацького складу тощо.

Висновки і пропозиції. Процес міжнародної кооперації закладів вищої освіти досить складний і багатоманітний. У нього переважно залучається багато учасників, що мають різні цілі, різні стартові можливості, різний потенціал, досвід і ступінь гнучкості. Отримання прогнозованих і бажаних результатів від співробітництва вимагає ефектив- 
ного управління, що має спиратися на об'єктивну картину в цій сфері. СВОТ-аналіз дозволяє поглянути на проблему комплексно, з різних сторін, виявити всі можливі альтернативи, переваги, загрози і запропонувати дієві стратегії для досягнення бажаного майбутнього. При цьому завжди слід пам'ятати, що невикористані можливості можуть перетворитися на загрози, якщо ними скористається конкурент, а ліквідована загроза, навпаки, може відкрити нові перспективи, нові горизонти для міжнародної кооперації.

\section{Список використаних джерел}

1. Антонюк Т. Міжнародне співробітництво та інтеграція у галузі освіти як важливий фактор конкурентоспроможності української освітньої системи. Наукові записки [Національного університету “Острозька академія”]. Історичні науки. 2013. Вип. 21. С. 149-155.

2. Антонюк Т. Співпраця українських ВНЗ з зарубіжними в умовах реформування національної системи освіти. Українознавчий альманах. 2013. Вип. 11. С. 233-236.

3. Бурдонос Л. І. Входження вищої школи України до міжнародної системи освіти. Актуальні проблеми економіки. 2015. № 12(174). С. 96-102.

4. Дерій Ж. В., Скиба С. А. Вплив механізмів державного регулювання на процеси функціонування людського потенціалу. Проблеми і перспективи економіки та управління. 2016. № 1(15). С. 18-30.

5. Дерій Ж., Зосименко Т., Шадура-Никипорець Н. Імплементація сталого розвитку як ключовий принцип галузевого співробітництва Україна - ЄС. Проблеми і перспективи економіки та управління. 2019. № 4(20). С. 9-18.

6. Мініна О. В. Проблеми побудови стратегії підприємства в сучасних українських реаліях. Проблеми і перспективи економіки та управління. 2019. № 3(19). С. 81-88.

7. Офіційний сайт Державного підприємства "Український державний центр міжнародної освіти" Міністерства освіти і науки України. URL: https://studyinukraine.gov.ua/zhittya-vukraini/inozemni-studenti-v-ukraini/.

8. Пажитнов К. К вопросу о сущности кооперации и ее определении. Вестник кооперации. 1915. Кн. 6. С. 2-23.

9. Рейтинг университетов мира QS (educationindex.ru). URL: https://www.educationindex.ru/ articles/university-rankings/qs?page $=1$.

10. Стратегія розвитку вищої освіти в Україні на 2021-2031 роки. Проєкт. URL: https://ru.osvita.ua/ doc/files/news/768/76871/1_STRATEHIYA_ROZVYTKU_VYSHCHOYI_OSVITY_V_U.pdf.

11. Чайка-Петегирич Л. Міжнародна співпраця університетів як невід’ємна складова трансформації вищої школи України у європейський освітній простір. Галицький економічний вісник. 2014. T. 45, № 2. C. 45-50.

12. Чаянов А. В. Краткий курс кооперации. 4-е изд. Москва : Центр. товарищество “Кооператив. изд-во", 1925. 78 с.

\section{References}

1. Antoniuk, T. (2013). Mizhnarodne spivrobitnytstvo ta intehratsiia u haluzi osvity yak vazhlyvyi faktor konkurentospromozhnosti ukrainskoi osvitnoi systemy [International cooperation and integration in the field of education as an important factor in the competitiveness of the Ukrainian educational system]. Naukovi zapysky [Natsionalnoho universytetu "Ostrozka akademiia"]. Istorychni nauky Scientific notes [National University "Ostroh Academy”]. Historical sciences, 21, pp. 149-155.

2. Antoniuk, T. (2013). Spivpratsia ukrainskykh VNZ z zarubizhnymy v umovakh reformuvannia natsionalnoi systemy osvity [Cooperation of Ukrainian universities with foreign ones in the conditions of reforming the national education system]. Ukrainoznavchyi almanakh - Ukrainian Studies Almanac, 11, pp. 233-236.

3. Burdonos, L. I. (2015). Vkhodzhennia vyshchoi shkoly Ukrainy do mizhnarodnoi systemy osvity [Entry of higher education in Ukraine into the international education system]. Aktualni problemy ekonomiky - Current economic problems, (12(174)), pp. 96-102.

4. Derii, Zh. V., Skyba, S. A. (2016). Vplyv mekhanizmiv derzhavnoho rehuliuvannia na protsesy funktsionuvannia liudskoho potentsialu [Influence of mechanisms of state regulation on the processes of human potential functioning]. Problemy i perspektyvy ekonomiky ta upravlinnia - Problems and prospects of economics and management, (1(15)), pp. 18-30. 
ТЕОРЕТИЧНІ ПРОБЛЕМИ РОЗВИТКУ НАЦІОНАЛЬНОЇ ЕКОНОМІКИ

5. Derii, Zh., Zosymenko, T., Shadura-Nykyporets, N. (2019). Implementatsiia staloho rozvytku yak kliuchovyi pryntsyp haluzevoho spivrobitnytstva Ukraina - YeS [Implementation of sustainable development as a key principle of sectoral cooperation Ukraine - EU]. Problemy i perspektyvy ekonomiky ta upravlinnia - Problems and prospects of economics and management, 4(20), pp. 9-18.

6. Minina, O. V. (2019). Problemy pobudovy stratehii pidpryiemstva v suchasnykh ukrainskykh realiiakh [Problems of elaboration of a company's strategy in the modern Ukrainian realities]. Problemy $i$ perspektyvy ekonomiky ta upravlinnia - Problems and prospects of economics and management, 3(19), pp. 81-88.

7. Ofitsiinyi sait Derzhavnoho pidpryiemstva "Ukrainskyi derzhavnyi tsentr mizhnarodnoi osvity" Ministerstva osvity i nauky Ukrainy [Official site of the State Enterprise "Ukrainian State Center for International Education" of the Ministry of Education and Science of Ukraine]. https://studyinukraine.gov.ua/zhittya-v-ukraini/inozemni-studenti-v-ukraini/.

8. Pazhitnov, K. (1915). K voprosu o sushchnosti kooperatsii i ee opredelenii [To the question of the essence of cooperation and its definition]. Vestnik kooperatsii-Cooperation Bulletin, (6), pp. 2-23.

9. Reityng universitetov mira QS (educationindex.ru) [QS World University Rankings]. $\mathrm{https}$ ://www.educationindex.ru/articles/university-rankings/qs?page=1.

10. Strategiia rozvitku vishchoi osvity v Ukraini na 2021-2031 roky. Proiekt [Strategy for the development of higher education in Ukraine for 2021-2031. Project]. https://ru.osvita.ua/doc/ files/news/768/76871/1_STRATEHIYA_ROZVYTKU_VYSHCHOYI_OSVITY_V_U.pdf.

11. Chaika-Petehyrych, L. (2014). Mizhnarodna spivpratsia universytetiv yak nevidiemna skladova transformatsii vyshchoi shkoly Ukrainy u yevropeiskyi osvitnii prostir [International cooperation of universities as an integral part of the transformation of higher education in Ukraine into the European educational space]. Halytskyi ekonomichnyi visnyk - Galician Economic Bulletin, 45(2), pp. $45-50$.

12. Chaianov, A. V. (1925). Kratkii kurs kooperatsii [Short course of cooperation]. Tsentr. tovarishchestvo "Kooperativ. izd-vo".

Бебко Світлана Вікторівна - кандидат економічних наук, доцент, доцент кафедри ділової іноземної мови та міжнародної комунікації, Національний університет харчових технологій (вул. Володимирська, 68, м. Київ, 01601, Україна).

Бебко Светлана Викторовна - кандидат экономических наук, доцент, доцент кафедры делового иностранного языка и международной коммуникации, Национальный университет пищевых технологий (ул. Владимирская, 68, г. Киев, 01601, Украина).

Bebko Svitlana - PhD in Economics, Associate Professor, Associate Professor of the Department of Business Foreign Language and International Communication, National University of Food Technologies (68 Volodymyrska Str., 01601 Kyiv, Ukraine).

E-mail: sried@mail.ua

ORCID: https://orcid.org/0000-0002-0687-3801 